\title{
The use of protein structure/activity relationships in the rational design of stable particulate delivery systems
}

\footnotetext{
M.H.B. Costa ${ }^{1}$,

W. Quintilio ${ }^{1}$,

O.A. Sant'Anna²,

A. Faljoni-Alário ${ }^{3}$ and P.S. de Araujo ${ }^{3}$
}

\author{
${ }^{1}$ Laboratório de Microesferas e Lipossomos, Centro de Biotecnologia and \\ ${ }^{2}$ Laboratório de Imunogenética, Instituto Butantan, São Paulo, SP, Brasil \\ IInstituto de Química, Universidade de São Paulo, São Paulo, SP, Brasil
}

\author{
Correspondence \\ M.H.B. Costa \\ Laboratório de Microesferas \\ e Lipossomos \\ Centro de Biotecnologia \\ Instituto Butantan \\ Av. Vital Brasil, 1500 \\ 05503-900 São Paulo, SP \\ Brasil \\ Fax + 55-11-3726-1505 \\ E-mail: bdacosta@edu.usp.br \\ Research supported by CNPq, \\ UNDP/World Bank/WHO Special \\ Program for Research and Training in \\ Tropical Disease (TDR), and FAPESP \\ (Nos. 94/5854-5, 00/10970-7, and \\ 00/14228-3 to M.H.B. Costa, and \\ 96/1405-7 to P.S. de Araujo).
}

Received February 15, 2002 Accepted March 15, 2002

\section{Abstract}

The recombinant heat shock protein (18 kDa-hsp) from Mycobacterium leprae was studied as a T-epitope model for vaccine development. We present a structural analysis of the stability of recombinant $18 \mathrm{kDa}$-hsp during different processing steps. Circular dichroism and ELISA were used to monitor protein structure after thermal stress, lyophilization and chemical modification. We observed that the 18 $\mathrm{kDa}-\mathrm{hsp}$ is extremely resistant to a wide range of temperatures (60\% of activity is retained at $80^{\circ} \mathrm{C}$ for $20 \mathrm{~min}$ ). N-Acylation increased its ordered structure by $4 \%$ and decreased its B-T1 structure by $2 \%$. ELISA demonstrated that the native conformation of the $18 \mathrm{kDa}$-hsp was preserved after hydrophobic modification by acylation. The recombinant $18 \mathrm{kDa}$-hsp resists to a wide range of temperatures and chemical modifications without loss of its main characteristic, which is to be a source of $\mathrm{T}$ epitopes. This resistance is probably directly related to its lack of organization at the level of tertiary and secondary structures.

Modern vaccinology combines recombinant DNA technology and protein chemistry to obtain safe subunit vaccines. Most vaccines are poorly immunogenic because a large number of antigens are membrane proteins and consequently they are not present in their native conformation in the vaccine. Others that are not as potent because they contain only B epitopes cannot stimulate cell memory. Their potential usefulness as vaccines depends on adjuvants that increase cell-mediated and humoral responses (1). Some of these antigens will need to be conjugated with protein carriers to provide long-

\section{Key words}

- Protein stability

- Hydrophobic modification

- Vaccine delivery system

- Drug delivery system

- Adjuvant term protection in young children (2). It is known that the heat shock proteins are involved in immunity (3) and particularly in $\mathrm{T}$ cell stimulation (4).

The recombinant heat shock protein (18 kDa-hsp) from Mycobacterium leprae contains some sequences that are similar to those of other heat shock proteins (4). Furthermore, the $18 \mathrm{kDa}$-hsp binds to T cells, which may confer to the bound carried antigen a proper presentation to induce $\mathrm{B} / \mathrm{T}$ cell immunity $(5,6)$. We developed the large-scale production of $18 \mathrm{kDa}-\mathrm{hsp}$ at low cost in order to be able to introduce this $\mathrm{T}$ cell 
stimulation into our vaccines $(7,8)$. Our main goal was to co-encapsulate the $18 \mathrm{kDa}$-hsp together with poor antigens within safe and pluripotent supports, such as liposomes $(9,10)$ or biodegradable microspheres (11). These supports can also be excellent vehicles with adjuvant and controlled release capacity. As pharmaceutical products they should be stable under storage conditions. The liposomes containing the $18 \mathrm{kDa}$-hsp are prepared in a stable condition by lyophilization (10). In addition to vehicle stability (10) it is important to study the chemical and thermal stability of the T-epitope source, i.e., the 18 kDa-hsp.

To elicit the preferential production of IgM, the protein must be associated with the outer layer of liposomes. To make this association with the liposome membrane possible, the $18 \mathrm{kDa}-\mathrm{hsp}$ was modified by acylation of the lysine residues to increase its hydrophobicity (9). The N-acyl-18 kDa-hsp circular dichroism spectra were obtained using a JASCO spectropolarimeter model

Table 1. The 18 kDa-hsp and N-acyl-18 kDa-hsp secondary structures.

\begin{tabular}{llcc}
\hline $\begin{array}{l}\text { Spectral signal (expressed } \\
\text { as component number) }\end{array}$ & Related structure & $\begin{array}{c}18 \mathrm{kDa}-\mathrm{hsp} \\
(\% \text { of } \Theta)\end{array}$ & $\begin{array}{c}\text { N-acyl-18 kDa-hsp } \\
(\% \text { of } \Theta)\end{array}$ \\
\hline 1 & $\alpha$-helix & 0 & 0 \\
2 & B-sheet or ß-T2 & 0 & 0 \\
3 & Disordered & 39.6 & 37.6 \\
4 & B-T1 & 33.7 & 37.2 \\
5 & S-S or aromatic & 26.7 & 26.2 \\
\hline
\end{tabular}

$\Theta$ in $10^{-3}$ degree $\mathrm{cm}^{2}$ decimol-1.

Figure 1. Residual activity as a function of temperature. The 18 kDa-hsp was frozen in the absence (squares) or the presence (circles) of trehalose and assayed by ELISA after thawing. Another assay was performed with the sample frozen in the absence (open triangle) or presence (filled triangle) of trehalose and then lyophilized. The sample was resuspended and incubated at the temperatures indicated.
J720. One 0.1-cm optical path circular cell was used to obtain all spectra.

The recombinant $18 \mathrm{kDa}-\mathrm{hsp}(1 \mathrm{mg} / \mathrm{ml}$ in PBS) was frozen, lyophilized, resuspended in water (final concentration of $1 \mathrm{mg} / \mathrm{ml}$ in PBS) and incubated for $30 \mathrm{~min}$ at different temperatures up to $80^{\circ} \mathrm{C}$. Protein stability was monitored by circular dichroism and ELISA.

For ELISA, the samples were added to plates and blocked with $0.1 \%$ BSA after $2 \mathrm{~h}$ at $37^{\circ} \mathrm{C}$. Subsequently, L5 (a monoclonal antibody; kindly provided by Dr. Carlos Alberto Moreira Filho, ICB, USP), antimouse peroxidase and TMB were added at 30-min intervals. After $15 \mathrm{~min}$ at room temperature, the reaction was stopped with $\mathrm{H}_{2} \mathrm{SO}_{4}$. Absorbance was read automatically at $450 \mathrm{~nm}(9)$.

When considering $18 \mathrm{kDa}$-hsp stability, its particular structural features should be taken into account. The primary structure of $18 \mathrm{kDa}$-hsp was derived from the nucleotide sequence (12). It is composed of 10 peptide regions delimited by nine proline residues intercalated by nine glycine residues. Both proline and glycine are known to destabilize the $\alpha$-helix. It does not contain S-S bonds that would maintain a rigid tertiary structure.

Therefore, its five lysine residues could be easily acylated, introducing at least five hydrophobic tails through its side chain. Furthermore this protein is not rich in aromatic residues, which would contribute to its rigidity by hydrophobic interactions. In fact, this protein is flexible and has no $\alpha$-helix content as determined by circular dichroism (Table 1). N-Acylation decreased disorder (component 3 ) by $2.0 \%$ and enhanced 3 -T1 (component 4 ) by $4.5 \%$. In general, the organizational level was not significantly changed by $\mathrm{N}$-acylation (Table 1).

The N-acylation of the $18 \mathrm{kDa}-\mathrm{hsp}$ did not alter its T-epitope conformation, as confirmed by its reactivity measured by ELISA (9).

The $18 \mathrm{kDa}$-hsp T-epitope conformation 
- expressed as immunological integrity in vitro - is preserved during entrapment within vehicles such as PLGA microspheres, liposomes, and protein supramolecular aggregates $(9,10)$. The residence time in the vehicles also does not alter its immunological integrity. The immune response induced by $\mathrm{N}$-acyl-18 kDa-hsp was as high as those mediated by the formulation within liposomes (9). This means that the simple introduction of hydrophobic tails increased the activity of $18 \mathrm{kDa}$-hsp. These ELISA tests were conducted using polyclonal antibodies, so it is impossible to distinguish if the antibodies are conformational or not. But, in spite of the small structural changes introduced by acylation, the N-acyl-18 kDa-hsp probably adopted the aggregation state of a mixed micelle, which is as good as a liposomal formulation $(9,10)$.

In countries with a warm climate, vaccine stability is mainly correlated with the cold chain, i.e., all transport steps from the production center to the patient at the clinical center during which the vaccine must be conserved refrigerated. Thermostability is an essential prerequisite for the successful development and dissemination of inexpensive, effective vaccine formulations. In many instances in the past, potential candidates have failed due to substantial losses at the production or downstream processing stages. In other cases, labile entities have been successfully produced at the commercial level, only to be inactivated by inadequacies in the handling procedures during transportation and distribution. Such occurrences have con- tributed to the failure of many vaccination campaigns $(13,14)$.

The use of trehalose was also investigated as a protective factor for the $18 \mathrm{kDa}$ hsp to permit its pasteurization and to improve its stability under storage and transport conditions, but it did not provide additional protection to the epitope activity.

The first question addressed was whether trehalose would protect the $18 \mathrm{kDa}$-hsp in the dry state, thus improving storage conditions. The particular conditions chosen mimic the thermal stress that dry vaccine formulations could endure during transportation. Laboratory storage is usually performed in low temperature freezers.

The $18 \mathrm{kDa}-\mathrm{hsp}$ is an extremely resistant protein. It resisted a wide range of temperatures, remaining active from $-100^{\circ} \mathrm{C}$ to $80^{\circ} \mathrm{C}$. After $30 \mathrm{~min}$ at $80^{\circ} \mathrm{C}, 60 \%$ of its activity could be recovered (Figure 1). The use of trehalose for the preservation of this protein proved to be redundant, since the protein by itself is extremely resistant to thermal stresses.

In terms of $18 \mathrm{kDa}$-hsp vehiculation, formulations within supramolecular aggregates, PLGA microspheres, liposomes and the Nacyl-derivative can be used to transport poor immunogens. The recombinant $18 \mathrm{kDa}-\mathrm{hsp}$ resists a wide range of temperatures and chemical modifications without loss of its main characteristic, which is to be a source of T epitopes. In this study, we demonstrated by circular dichroism that this resistance is directly related to its lack of organization at the level of tertiary and secondary structures.

\section{References}

1. Bollow WR, Sherwood J A, Neva FA, Gordon DM, Wirtz RA, Wasserman GF, Diggs $\mathrm{CL}$, Hoffman SL, Hollingdale MR, Hackmeyer WT, Schneider I, Chulay J D, Young J F \& Reeve P (1987). Safety and efficacy of a recombinant DNA Plasmodium falciparum sporozoite vaccine. Lancet, 1: 1277-1281.

2. Frasch CE (1990). Production and control of Neisseria meningitidis vaccines. In: Avshalom Mizrahi (Editor), Advances in Biotechnological Processes, Bacterial Vaccines. Wiley-Liss, New York, NY, USA, 123-145.

3. Doherty TM, Booth RJ, Love SG, Gibson JJ , Harding DRK \& Watson JD (1989). Characterization of antibody-binding epitope from the $18 \mathrm{kDa}$ protein on Myco- bacterium leprae. J oumal of Immunology, 142: 1691-1695.

4. Harris DP, Backström BT, Booth RJ , Love SG, Harding DR \& Watson J D (1989). The mapping of epitopes of the 18-kDa protein of Mycobacterium leprae recognized by murine $T$ cells in a proliferation assay. J ournal of Immunology, 143: 2006-2012.

5. Schneerson R, Barrera O, Sutton A \& 
Robbins J B (1980). Preparation, characterization and immunogenicity of Haemophilus influenzae type $B$ polysaccharide conjugates. J ournal of Experimental Medicine, 152: 361-376.

6. Anderson PW, Pichinero ME, Insel RA, Betts R, Eby R \& Smith DH (1986). Vaccines consisting of periodate-cleaved oligosaccharides from the capsule of Haemophilus influenzae type $B$ coupled to a protein carrier: structure and temporal requirements for priming in the human infant. J ournal of Immunology, 137: 11811186.

7. Costa MHB, Ueda CMPM, Sato RA, Liberman C \& Raw I (1995). Procedures for scaling up the recombinant $18 \mathrm{kDa}$-hsp lepra protein production. Biotechnology Techniques, 9: 527-532.

8. Sato RA \& Costa MHB (1996). Bioprocess design: study of a case. Biotechnology Letters, 18: 275-280.

9. Costa MHB, Sant'Anna OA, de Araujo PS, Sato RA, Quintilio W, Silva LVN, Matos CRT \& Raw I (1998). Conformational stability and antibody response to the $18 \mathrm{kDa}$ heat shock protein formulated into different vehicles. Applied Biochemistry and Biotechnology, 73: 19-28.

10. Esteves MI, Quintilio W, Sato RA, Raw I, de Araujo PS \& Costa MHB (2000). The stabilisation of immunoconjugates by trehalose. Biotechnology Letters, 22: 417420.

11. Costa MHB, Sant'Anna OA, Sato RA, Barratt G \& Fattal E (1998). Antibody response and T-epitope conformational analysis of a heat shock protein encapsulated within PLGA microspheres. Proceedings of the 2nd World Meeting APGI/
APV, Editor APGI International Congress Publications, Paris, France, 518-519.

12. Booth RJ , Harris DP, Love J M \& Watson J D (1988). Antigenic proteins of Mycobacterium leprae - Complete sequence of the gene for the 18-kDa-hsp protein. J ournal of Immunology, 140: 597-601.

13. Gribbon EM, Sen SD, Roser BJ \& Kampinga J (1996). Stabilisation of vaccines using trehalose (Q-T4) technology. In: Brown F (Editor), New Approaches to Stabilisation of Vaccines Potency. Developments in Biological Standardization. Karger, Basel, Switzerland, 87: 193-199.

14. Zaffran M (1996). Vaccine transport and storage: environmental challenges. In: Brown F (Editor), New Approaches to Stabilisation of Vaccines Potency. Developments in Biological Standardization. Karger, Basel, Switzerland, 87: 9-17. 